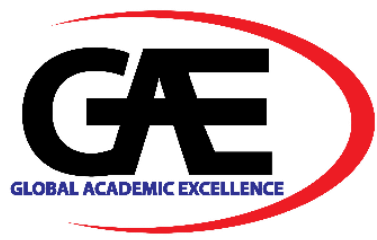

\title{
ANALYSIS ON THE HALAL STATUS OF A MEDICAL DEVICE: A STUDY ON THE SURGICAL SUTURE
}

\author{
Nur Farhani Zarmani ${ }^{1 *}$, Mohd Anuar Ramli ${ }^{2}$, Shaikh Mohd Saifuddeen Shaikh Mohd Salleh ${ }^{3}$, Mohd \\ Zaid Daud ${ }^{4}$, Mohd Amzari Tumiran ${ }^{5}$
}

1 Academy of Contemporary Islamic Studies, Universiti Teknologi MARA, Malaysia

Email: nurfarhani@uitm.edu.my

2 Department of Fiqh \& Usul, Academy of Islamic Studies, University of Malaya, Malaysia

Email: mohdanuar@um.edu.my

3 Center for Science \& Environment Studies, Institute of Islamic Understanding Malaysia (IKIM), Malaysia

Email: shaikh@ikim.edu.my

4 Academy of Contemporary Islamic Studies, Universiti Teknologi MARA, Malaysia

Email: mohdzaid@uitm.edu.my

5 Academy of Contemporary Islamic Studies, Universiti Teknologi MARA, Malaysia

Email: amzari92@uitm.edu.my

* Corresponding Author

\section{Article Info:}

\section{Article history:}

Received date:30.04.2021

Revised date: 21.06 .2021

Accepted date: 15.07 .2021

Published date: 15.09.2021

\section{To cite this document:}

Zarmani, N. F., Ramli, M. A., Salleh, S. M. S. S. M., Daud, M. Z., \& Tumiran, M. A. (2021). Analysis On The Halal Status Of A Medical Device: A Study On The Surgical Suture. International Journal of Halal Ecosystem and Management Practices, 1 (1), 01-07.

DOI: $10.35631 /$ IJHEMP.11001.

\begin{abstract}
:
There is a recent demand for halal certification from another healthcare sector which is medical devices, which cover all types of medical equipment used in hospitals from simple equipment such as bandages to complex equipment such as ventilators. This matter has been raised by the industry as halal labelling is a requirement to penetrate the market of Islamic countries such as Saudi Arabia, Turkey, and Pakistan. Even it seems critical to proving halal status for the medical devices that incorporate animal tissues, in contact with or invasive to the body, and produce a reaction to the body, this does not deny the demand for other types of devices. This study will focus on the halal issues related to medical devices which are widely used to stitch and close the wounds of patients after surgery or injury, namely sutures. This study seeks to identify the status of suture usage from the perspective of Islamic ruling. To achieve this objective, a qualitative research method through library research, as well as field studies involving in-depth interviews with the industry players, both medical device and religious authorities, Islamic scholars, and medical practitioners. The interviews were recorded, transcribed, translated, coded, and reconciled with the aid of Atlas.ti software (version 7) to identify themes and subthemes for this study. The results show that with regard to the status of resources and processes, and the application of al-darurah (necessity) concept.
\end{abstract}




\section{Introduction}

From a scientific and Islamic viewpoint, studies related to the study of the use of sutures in the field of halal medicine have not been comprehensively discussed. While past suture studies have touched on many scientific aspects, there is still no significant debate on the legal status of suture use in medicine. In the Medical Devices Act (Act 737), the definition of medical devices defines medical devices as any device, instrument, device, computer, tool, implant, reagent or in vitro calibrator, software, material or other similar device intended for use in the human body, taking into account public safety, public health or public risk concerns (Kamal, 2014). In the treatment process, the key role of the use of a medical device is the opposite of the drug product, as it does not require metabolic, immunological or pharmacological reactions. It is not used as a primary instrument that generates pharmacological, immunological or metabolic reactions, but is supported in its function (Sharples et al., 2012).

Each country has a different classification definition of medical devices. The classification of medical devices is the responsibility and regulation of the authorities. Authorities identify medical device classes based on several aspects such as the complexity of the form of the medical device, the characteristics of its use, and also the risk imposed. In Malaysia, medical devices are divided into four classes according to the level of risk. Risk means the probability of harm occurring and the severity of the harm. For a device product to be manufactured, the establishment must determine the category of the device based on the level of risk posed by the medical device, its intended use and the potential of the human body to be exposed to danger. Suture is one of the most commonly used medical devices in medical procedures. Essentially, suture is a technique of closing wounds due to surgical incision or injury. Suture actually acts as a tool that supports wound grafting and healing and there are various methods of wound closure in medical practice. For example sewing techniques, glue, stapler and zip. This study only involves sutures that use sewing techniques to cover wounds, which are in the form of threads, fine wire and so on that are used to sew wounds or incisions on the body (Zarmani, 2017).

\section{Literature Review}

Regarding the halal and haram aspects, Imam al-Ghazali specializes in the chapter on halal haram in the book Ihya' 'Ulum al-Din. In addition, 'Abd al-Karim Zaidan in his book Majmu'at Buhuth Fiqhiyyah explains from the perspective of medicine. The rules of fiqh that can be applied have also been outlined by al-Qaradawi and Shawqi Abduh al-Sahi. The method of fiqh that is tried to be highlighted in this study is the method of darurah.

The halal discussion involves aspects of fiqh by Jamaluddin (2015) through the study of alcohol. The study conducted by Shafii \& Khadijah (2012) however, sees that the aspect of halal food production should be held accountable to the producers. This is because the manufacturer should be able to track the movement of the product as well as ensure that the process is not in violation of Islamic law. The study indirectly provides guidance to industry players in producing halal food products at the processing, transportation and distribution levels. Halal studies in the medical industry, discussed by Abd. Aziz et al. (2009). The study also stated the status and challenges faced in obtaining and developing halal medicine. The Copyright (C) GLOBAL ACADEMIC EXCELLENCE (M) SDN BHD - All rights reserved 
discussion on the issue of halal pharmaceuticals also raises the status of the use of gelatin as a medicinal material as studied by Harmen Shah and Faridah Yusof. The issue of justification arises for consumers to question halal and illegal drugs during treatment thus encouraging the industry players to produce products that comply with shariah.

The use of filth in medical products has also been conducted extensively by Mohd Zarif et al. (2013). This study has analyzed the views of jurists, Muslim medical practitioners as well as the interpretation of Islamic law and related fatwas. Catherine Easterbrook and Guy Maddern have also studied the use of porcine and bovine surgical products among the Jewish, Muslim and Hindu communities by analyzing the views of religious leaders in Australia. Axelina Eriksson conducted a study on the conflict in the use of animal products from animals with the beliefs of six religions, namely Christianity, Islam, Hinduism, Buddhism, Sikhism and Judaism.

The usage of najs in medicinal products is also discussed by Middle Eastern researchers. For example, Al-Jam'iyyah al-'Ilmiyyah Al-Sa'udiyah li Al-Dirasat Al-Tibbiyyah Al-Fiqhiyyah has discussed the issues of medical fiqh. Badr Muhammad 'Id Mubarak Al-'Azami explains istihalah in various applications (Badr al-Din, 1949). The use of porcine elements based on the method of 'general al-balwa, istihalah and istihlak is also discussed by Ali bin Ahmad AlMuta'. Legal aspects and fatwas for elements commonly used in medicines such as gelatin and alcohol are also studied by Ab. Halim et al. (2014). The study was also supported by Ab Latiff \& Zakaria (2016) who explained about the implementation of MS2424. Based on previous studies, although there is a lot of discussion about sutur, there are gaps in discussion related to suture from a halal and haram perspective. Similarly, studies related to the risks and effects of suture use on patients. Thus, this study will analyze the content of suture and the law of the use of suture from the perspective of fiqh.

\section{Methodology}

In this qualitative study, data were obtained by interviewing informants on use of sutures from both aspects of science and Islam. Data were collected and recorded in audio form. Semistructured interviews were conducted for about an hour with the medical practitioners, Islamic scholars, medical device manufacturers and authorities which are the Department of Islamic Development (JAKIM) and Medical Devices Authority (MDA). The transcripts of the interviews were analysed using content analysis method with the help of Atlas/ti software version 7 .

\section{Results}

The medical device industry is witnessing the competition among industry players of suture. The production of these suture products should be determined by its halal and haram status so that the suture used is not only clean and pure, but also guaranteed in terms of safety and efficiency. There are various types of sutures as a result of technological advances and developments in the medical device industry, be it sutures that act to cover wounds through sewing techniques, patches or adhesions using glue or stitches. Accordingly, the determination of the law of suture use has considered four aspects namely the source of raw materials, and the process.

Basically, it is compulsory for Muslims to seek something that is halal, based on a hadith narrated by Anas bin Malik that the Prophet Muhammad SAW said: 
"The Prophet SAW said: Finding what is halal is an obligation on every Muslim."

\section{The Halal Status of Surgical Suture based on the Source of Origin}

Generally, treatment using haram elements is not allowed, based on the hadith Rasulullah (pbuh) narrated from 'Abdullah bin Mas'ud.

"Indeed, Allah does not make healing on things that are forbidden" (Ibn Hajar, 2004).

Determining the hukm of sutures, the first aspect to consider is the source of the suture, which may classify into two main sources, namely natural or synthetic. It is critical to identify its sources due to the complex medical device ecosystem. There are claims that sutures made of intestines of haram animals such as pigs, and there is still no manufacturer which can verify their suture products derived from halal sources. The use of animal-based sutures has long been practiced in the field of healthcare. There are three types of animal-based sutures that are most commonly used, namely catgut sutures, reconstituted collagen sutures (RC) and even silk sutures.

The material of these three types of sutures is extracted from protein sources of various animals. Both catgut and reconstituted collagen (RC) sutures, have similar shape and will decompose in the body, made of livestock. It is possible to make catgut from the intestines of all kinds of animals, such as goats, sheep, cows, and pigs. As for RC sutur, it is usually produced from the long flexor tendon of bovine, such as cattle or buffalo. The prohibition of pigs has been stated by Allah in specific Quranic verse:

"He has only forbidden you to eat carrion, blood, swine, and what is slaughtered in the name of any other than Allah..." (Qur'an 2:173)

Catgut suture which is made of animal intestine may be derived of non-halal animals such as pigs, cows, goats and sheep. Since this material is mostly imported, it cannot be confirmed the source of origin and the status of slaughtering. The obligation of proper slaughtering according to Shariah has been stated through the verse:

"Therefore, eat of that on which Allah's name has been mentioned if you are believers in His communications." (Qur'an 6:118)

Latest discussion on Islamic slaughtering method was discussed extensively by Aghwan \& Mac Regenstein (2019). Suture from the intestinal part of non-halal animals, such as pig intestines and ruminants that are not slaughtered cannot be used in medicine. However, it can be allowed in the situation of emergency or darurah. While for synthetic derived suture, the determination of $h u k m$, it is permitted considering it is produced from a safe polymer material.

\section{The Halal Status of Surgical Suture based on the Processing Activity}

The halal status of suture products was also determined by the processing activity of the suture production including usage of chemical and processing aids. The chemicals and processing aids refers to all materials other than the main raw materials, which are used for the purpose of cleaning, sterilization, and also the maintenance of sutures. Unfortunately, the status of 
chemicals and processing aids yet to be defined, thus generate doubts on the status of suture (Mamat, N. E, personal communication, December, 1, 2015)

Sterilization of sutures which use alcohol provoke for verification that alcohol source is not by product of the brewery industry. In the practice of suture production, sterilization of products used industrial alcohol synthesized from petroleum, and not considered as najs. The application of alcohol as a disinfectant has also been mentioned in the $8^{\text {th }}$ Nadwah Fiqh of Islamic Medicine, organized by the Islamic Organisation for Medical Sciences held in Kuwait in 1995. Since it is permitted to use industrial alcohol as the production does not involve khamr (wine) industry, sterilization of sutures using industrial alcohol is also halal.

The determination of halal critical issues of suture is not resolved in the manufacturing facility; hence it is significant to address the logistics issues. Even though the product is verified as halal, the status shall be sustained along the supply chain. Prevention on mixing of highly packed halal and haram suture during storage and transportation is potentially possible by complying with the halal logistics requirement MS2400. Halal logistics is important to maintain the integrity of the product from the farm to the hospital bedside.

\section{Discussion}

The fundamental of hukm of using najs is forbidden based on the hadith narrated by Abu Darda', the Prophet SAW said:

"Allah has sent down both the disease and the cure, and He has appointed a cure for every disease, so treat yourselves medically, but use nothing unlawful." (Abu Daud, 2008).

Since the suture is used for wound stitching in various surgical and treatment procedures, the application is categorized into two levels of maslahah or needs, namely al-daruriyyah (emergency/urgency) and al-hajiyyah (necessity). Al-daruriyyah refers to a form of maslahah that is related to the preservation of human life. The absence of it may destroy human life, for example, individu who do not have halal food to eat, except those that are forbidden like carcasses. If he did not consume the carcass, his life would be in danger or die. Therefore, it is permitted for him to eat the carcass at that time due to an emergency. Similarly, the use of najs for medical intention is allowed when there is no treatment from a halal source either in the situation of darurah or hajah (Desa, 2012).

The fact of protecting human life not only means to preserve life from harm, but also to protect it from anything that may contribute to risk and harm, such as uncontrol exposure to disease and lack of initiative to do treatment when afflicted with disease. Life sustainability which ranked the second after religion, gives great emphasis on us as it is protected under the Maqasid al-Shariah (Objectives of the Islamic Law).

It is possible that there are sutures that contain the element of najs, since no suture products is halal certified. Najs, in the situation of catgut suture production includes all haram sources either najs mughallazah element (pig intestine) or non-slaughtered animals (ruminant such as bovine intestine) as well as from harmful toxic chemicals.

However, there are Quranic verses that allow the use of material considered as najs to preserve human life.

Copyright $\odot$ GLOBAL ACADEMIC EXCELLENCE (M) SDN BHD - All rights reserved 
"Verily Allah only forbids you to eat carcasses, blood, pork and slaughtered animals not because of Allah then whoever is forced (to eat it because of emergency) while he does not want it and does not exceed the limit (at the rate of the thing eaten), then he is not a sinner. Lo! Allah is Oft-Forgiving, Most Merciful.” (Qur'an 2:173)

The priority of choosing maslahah for health and safety purposes rather than maslahah to avoid using najs is higher as mentioned by 'Izz ibn' Abd al-Salam. Al-Darurah permitted things that were originally forbidden in normal situations. The concept of darurah implied in allowing the use of syubhah or haram catgut sutures. This is in line with the method of fiqh:

\section{"Darurah requires things that are forbidden"}

However, this permission is not absolute unless there is no other medical alternative (Zulkifli Mohamad Al-Bakri, personal communication, November, 6, 2015). In addition, compulsion in darurah situations shall not exceed the limits of necessity (intended to enjoy delicacies as stated in the method of fiqh:

"Things (which are later forbidden to be) should be due to darurah should be limited to the proper rate"

In this situation, there is an urgency (al-darurah) and necessity (al-hajah) to utilize syubhah or haram catgut suture as a tool for wounds closure if there is no other suitable halal sutur alternative when the darurah occurs in line with the views of classical and contemporary scholars. Therefore, it is permissible to use sutures from najs elements as wound dressing material when there is no alternative to halal sutures, which shall be used as a necessity and not to exceed the limits. By adopting the theory of darurah, the hukm of haram sutur is compulsory when there is no halal sutur. Whenever the darurah situation is resolved, such as the availability of halal sutur, then the usage of syubah or haram suture is prohibited (Hammad, 2004).

\section{Conclusion}

The suture is one of the suitable medical devices use to initiate an understanding towards halal medical device production. Due to the facts that various halal critical issues are identified along the supply chain.

\section{Acknowledgement}

We thank all informants and the faculties especially Academy of Contemporary Islamic Studies (ACIS), Universiti Teknologi MARA for the technical support.

\section{References}

Ab. Halim, M. A., Mohd Salleh, M. M., Mohd Kashim, M. I. A., Ahmad, A. A., \& Nordin, N. (2014). Halal pharmaceuticals: legal, shari'ah issues and fatwa of drug, gelatine and alcohol. International Journal of Asian Social Science, 4(12), 1176-1190.

Ab. Latiff, J. \& Zakaria, Z. (2016) Pelaksanaan Malaysian Standard MS 2424:2012 Halal Pharmaceuticals-General Guidelines. Journal of Shariah Law Research, 1(1), 119-140. 
Abd. Aziz, N., Hassan, Y., Abdul Razzaq, H. A., Hashim, H., \& Yahaya, M. Y. (2009). Halal medication issues: status and challenges. In The 8th Saudi International Pharmaceutical Conference and Exhibition. Saudi Pharmaceutical Society, Riyadh, 2628 April (pp. 143).

Abu Daud, S. (2008). Hadith Compilation by Abu Daud. Dar Al-Kotob Al-Ilmiyah.

Aghwan, Z. A., \& Mac Regenstein, J. (2019). Slaughter practices of different faiths in different countries. Journal of Animal Science and Technology, 61(3), 111.

Al-Qaradawi, Y. (2002). Fiqh Al-Taharah. Maktabah Wahbah.

Badr al-Din, A. A. M. (1949). Mukhtasar Al-Fatawa Al-Misriyya Ibn Taymiyyah. Beirut: Dar al-Kotob al-Ilmiyah.

Desa, R. (2012). Aplikasi Kaedah Al-Darurah Dalam Perkhidmatan Kesihatan Di Malaysia (Unpublished doctoral dissertation) Universiti Malaya.

Hammad, N. (2004). Al-Mawad al-Muharramah wa al-Najisah fi al-Ghiza' wa al-Dawa' bayna al-Nazariyyah wa al-Tatbiq. Dar al-Qalam.

Ibn Hajar, S. (2004). Bulugh al-Maram min Adillat al-Ahkam. Al-Maktab al-Islami li-Ihya' alTurath.

Jamaludin, M. A. (2015). Penentuan Kadar Alkohol Dalam Produk Minuman Menurut Perspektif Fiqh Dan Sains (Unpublished doctoral dissertation). Universiti Putra Malaysia.

Kamal, D. D. (2014). Akta Peranti Perubatan 2012 (Akta 737). Jurnal Kanun, 26, 147-51.

Mohd Zarif, M. M., Abd Murad, A. H., \& Md Yusof, A. F. (2013). The use of forbidden materials in medicinal products: an Islamic perspective. Middle-East Journal of Scientific Research, 16, 5-10.

Shafii, Z., \& Khadijah, W. W. S. (2012). Halal traceability framework for halal food production. World Applied Sciences Journal, 17(12), 1-5.

Sharples, S., Martin, J., Lang, A., Craven, M., O’Neill, S., \& Barnett, J. (2012). Medical device design in context: A model of user-device interaction and consequences. Displays, 33(4-5), 221-232.

Zarmani, N. F. (2017). Penggunaan sutur dalam bidang perubatan: Analisis dari perspektif sains dan Islam (Unpublished doctoral dissertation) University of Malaya. 